\title{
THE LUBELSKIE REGION AS A BENEFICIARY OF THE EU COHESION POLICY FUNDS - EXPERIENCES AND PROSPECTS
}

\author{
JOANNA SZAFRAN \\ Maria Curie Skłodowska University in Lublin, Faculty of Economics, POLAND \\ e-mail: joanna.szafran@gmail.com
}

RECEIVED
ACCEPTED
JEL
CLASSIFICATION

KEYWORDS

ABSTRACT

\author{
18 January 2018 \\ 2 September 2018 \\ $\mathrm{H} 76, \mathrm{O} 20, \mathrm{R} 10, \mathrm{R} 58$
}

regional development, Eastern Poland's regions, EU cohesion policy, EU funds

Lubelskie voivodeship belongs to Eastern Poland regions, these face numerous difficulties such as economic backwardness, underdeveloped infrastructure, ageing and depopulation, as well as border location. As a result, Lubelskie voivodeship was qualified as the least development areas (NUTS 2) in the European Union. The goal of the article is to investigate the scopes and the directions of allocation of the EU assistance in programmes in the years 2004-2006 and 2007-2013, as well as in the current programming period. Lubelskie voivodeship is an active participant of EU funds and uses the growth opportunities offered by regional programme and Development Eastern Poland Programme. Compared to other voivodeships, received one of the lowest values of co-financing under national programmes. The largest EU support for the Lubelskie voivodeship in the years 2004-2013 was spent on transport, enterprises, social and local infrastructure. In the current programming period, it is planned to increase funding for enterprises, strengthening the cooperation between science and business, low carbon economy and RES, labour market and social inclusion.

\section{Introduction}

Lubelskie voivodship belongs to Eastern Poland regions were historically poorly urbanized, industrialized, infrastructurally developed and undercapitalized and thus less socially and economically developed relative to the rest of Poland. The transformation has brought new challenges and regional disparities deepened. Many researchers point out that the processes of internationalization and structural change in CEE tend to favor 
metropolitan and western regions, as well as regions with strong industrial base (Gorzelak, Goh, Fazekas, 2012, pp. 190-192, 226). Lower levels of both income per capita and productivity are also associated with lower level of entrepreneurship and innovation in rural regions (McCann, 2015, p. 19; Kudełko, 2013, p. 214). Academic research and evaluation studies show the impact of EU funds on the acceleration of economic growth and real convergence of the Central and Eastern Countries (Halmai, Vásáry, 2010, p. 236; Rapacki, Próchniak, 2010, p. 523) but have reached widely differing conclusions on the results of interventions structural and cohesion funds in theirs regions (Bachtler, Berkowitz, Hardy, Murvska, 2016, pp. 9-80). Critics of the EU's cohesion policy argue that it weakens the competitiveness of the regions (Rodrigues-Pose, Fratesi, 2004, p. 14; Gorzelak, 2007, pp. 24-31), accuse her lack of visible convergence and even between regions divergence (Smętowski, Wójcik, 2009, p. 52). According to macroeconomic models (Hermin, Mamor3, Eulmpact, QUEST III) the Polish Eastern regions would speed up their growth and employment (Bradley, Untiedt, Zaleski, 2016; Kaczor, Mackiewicz-Łyziak, Michniewicz, 2011; European Commission 2014, pp. 230-234). There are the differences between self-governments in the absorption of EU support and the directions of their spending, and consequently in the development results (Churski, Perdał, Herodowicz, 2016, pp. 105-114; Swianiewicz, 2012, pp. 9-24; Tomaszewski, 2011, p. 114). Is the Lubelskie voivodeship active participant of the EU Funds and uses the growth opportunities offered by the EU cohesion policy? The aim of the paper is to investigate the scopes and the directions of allocation of the EU assistance in programs in the years 2004-2006 and 2007-2013, as well as in the current programming period.

\section{Method}

The article provides a case study of the use of the EU cohesion policy Funds on the example of Lubelskie voivodeship. The analysis final reports on the implementation the National Development Plan for 2004-2006 as well as sectoral and the Integrated Regional Operational Programme, the National Cohesion Strategy 20072013, the Partnership Agreement for Poland, national programmes and the ROP Lubelskie for 2007-2013 and 2014-2020 have showed the region participation and its activity compared to others regions. Valuable data on the number of contracts signed and the value of co-financing from the EU Funds has been collected from the Final Reports prepared by Ministry of Regional Development (Ministry of Development) and the Board of the Lubelskie voivodeship, the KS SIMIK 07-13 and the website "Map of the EU grants". Statistical data showing some changes in this voivodeship has come from the Central Statistical Office and EUROSTAT.

\section{Ahsorption of the EU cohesion policy funds in the Lubelskie voivodeship in the years 2004-2006}

After Poland's accession to the European Union (EU) in 2004, the entire country has been provided with aid support as a less developed area (Objective 1). The lowest level of the GDP per capita was recorded in the Lubelskie voivodeship, which became the poorest region of the EU (achieving only $31.9 \%$ of the EU25 average in 2002 and 35\% in 2004). ${ }^{1}$ As a result, all voivodeships received support from four Structural Funds (European Regional Development Fund - ERDF, European Social Fund - EFS, European Agriculture Guidance and GuaranteeGuarantee Section - EAGG and Financial Instrument for Fisheries Guidance - FIFG) as well as the Cohesion Fund (CF). The funding from Structural Funds amounting to EUR 8.6 billion was allocated for the implementation of the

${ }^{1}$ Eurostat \& Gross Domestic Product Regional Account in 2010, Central Statistical Office, Statistical Office in Katowice, Katowice 2012, p. 26. 
Community Support Framework (CSF) and five Sectoral Operational Programmes (SOP), one Integrated Regional Operational Programme (IROP) and a Technical Assistance Programme (TA), as well as two Community Initiatives: INTERREG III and EQUAL. Absorption of the CF was based on the "Cohesion Fund Strategy". From 2000 to 2006 almost EUR 5.64 billion was raised from the CF and ISPA.

One fifth of the EU aid pool was allocated to the IROP implementation. As the only regional targeted program, it covered all voivodeships and was co-financed by both the ERDF (EUR 2530.4 million) and the ESF (EUR 438.4 million). The greater share of structural funds (about $60 \%$ ) was allocated to the implementation of five sectoral Operational Programmes co-financed by individual funds. The distribution of the CF aid was due to its sectoral structure (national roads, motorways, railway, water and sewage).

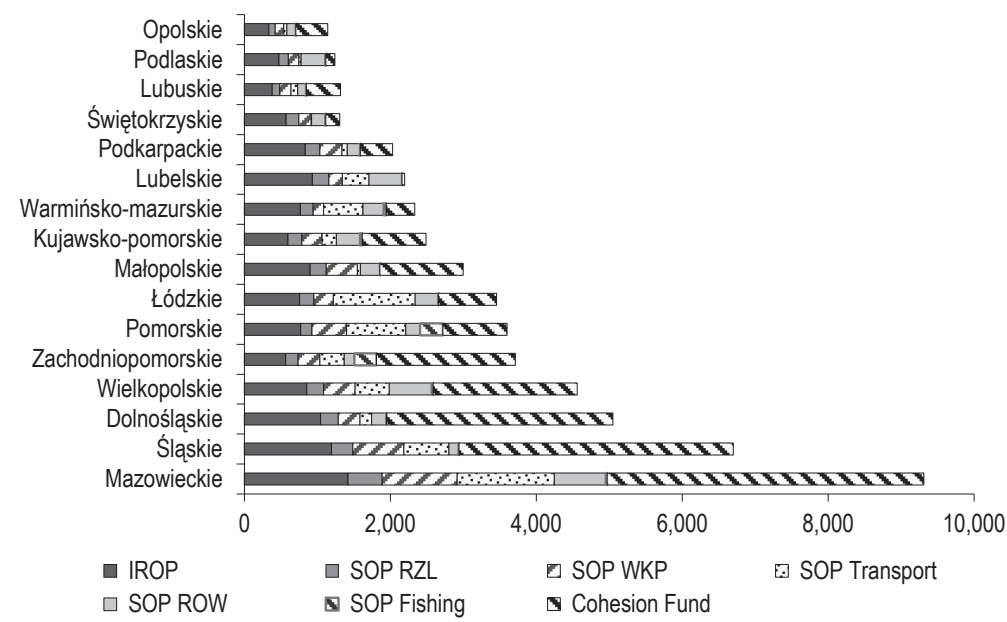

Figure 1. The value of funding under the Operational Programs and the Cohesion Fund in the period 2004-2006 by voivodeships (in PLN million)

Source: own estimations from data of Ministry Regional Development "Map of the EU grants" (August 2017).

An analysis of the regional distribution of support from the EU funds in the years 2004-2006 indicates that almost half of the funding was allocated for the co-financing of projects in the four richest voivodeships. As a result, the projects of the highest value were implemented there. Lublin's share in EU funds in the first period of membership amounted to $4 \%$. In terms of the number of subsidized projects, the Lubelskie took second place after Mazovian voivodeship. However, this resulted in a lower average value of projects from the Lublin region compared to the national average. In the Eastern Poland, including the Lublin region, the bulk of EU co-financing was obtained from the IROP. The IROP has been more focused on expanding the basic infrastructure and improving the living conditions than strengthening the competitiveness of regional economies, which was to be its strategic objective (Szafran, 2010, p. 82). Due to an application of algorithm in the distribution of the IROP allocations, which marginally reflected the level of development of voivodeships, most of the funds (almost 1/3) was allocated to three most developed voivodeships: Mazovian, Silesian and Lower Silesian. The Lubelskie voivodeship took the next place (with the co-financing amounting to over PLN 800 million), distinguishing itself with the higher number of contract 
concluded, in particular in terms of extension and modernization of local roads, water and sewerage networks, social infrastructure, improving access to ICT, professional reorientation of people from agriculture, promotion of entrepreneurship and creation the Regional Strategy for Innovation (Ministerstwo Rozwoju Regionalnego, 2010, pp. 40-215). However, the average value of these projects was lower or even the lowest in the country.

The Mazovia region also prevailed in sectoral programmes, and above all in the allocation of the Cohesion Fund. In addition, high shares of co-financing for sectoral programmes were recorded in the following voivodeships: Łódź (SOP Transport), Silesian, Wielkopolska and Małopolska (improvement of the competitiveness of enterprises, SOP WKP), Silesian, Lower Silesian, Lubelskie, Małopolska and Podkarpackie (development of human resources, SPO RZL), Pomeranian and West Pomeranian (SOP Fishing). In the case of Lubelskie voivodeship, there is a high demand for training and scholarship programmes, as well as support for starting own business. Furthermore, there was a relatively high share of spending on social infrastructure and health care. As far as direct corporate support is concerned, the subsidy in the Lubelskie region does not diverge from the national average and is intended mainly for investment in physical capital and access to external financing of investments. Due to the agricultural character of the region, significant aid (SOP ROW) was spent primarily on the modernization of agricultural holdings, agri-food sector and on facilitating the start of young farmers (Ministerstwo Rozwoju Regionalnego, 2008, p. 11). Although the main objective of the Cohesion Fund is to strengthen social, economic and territorial cohesion at national rather than regional level, it was the dominant source of aid in most voivodeships. The Lubelskie received the lowest share in the allocation of the $\mathrm{CF}$, which required the implementation of large infrastructural projects and the provision of own contribution.

Summing up the first period of Poland's membership in the EU, it clearly show the dominance of sectoral policies over regional policies and, the prevalence of priorities focused on the development of the entire country, rather than the problematic and poorer regions, which was the Lublin region. Existing development disparities could not be alleviated in such short time by one regional programme which was, in fact, centralized. All voivodeships in the IROP, regardless of their specificity and adopted development strategy, had the same set of priorities and similar proportions of financing (Jankowska, Kierzkowski, Knopik, 2005, p. 288).

\section{Directions of allocation of cohesion policy funds in the 2007-2013 programming period}

The reform of the EU budget and cohesion policy has resulted in a change of its objectives, principles and financing instruments, based on the new legislative acts for the years 2007-2013. The entire country has been included in the Convergence objective which was a priority of the Structural Funds and the Cohesion Fund, accumulating over $80 \%$ of their financial resources. Two of the four Structural Funds remained: ERDF and ESF. Community Initiatives were also extinguished, with the exception of INTERREG, the programmes of which were taken over by the new objective - European Territorial Cooperation (ETC).

Between 2007 and 2013 the EU cohesion policy was implemented in Poland by the National Cohesion Strategy, 6 national and 16 regional operation programmes (ROP). Each voivodeship implemented its own programme, managed by the voivodeship self-government. 
Table 1. Value of co-financing of projects implemented in the Lubelskie voivodeship according to EU programmes and funds, as of March 31, 2017

\begin{tabular}{lccccccc}
\hline Program & $\begin{array}{c}\text { Infrastructure } \\
\text { Environment }\end{array}$ & $\begin{array}{c}\text { Innovative } \\
\text { Economy }\end{array}$ & $\begin{array}{c}\text { Human } \\
\text { capital }\end{array}$ & $\begin{array}{c}\text { Development } \\
\text { of Eastern Poland }\end{array}$ & TA & $\begin{array}{c}\text { ROP } \\
\text { Lubelskie }\end{array}$ & $\begin{array}{c}\text { ROP } \\
\text { Warmińsko- } \\
\text { mazurskie }\end{array}$ \\
\hline EU Fund & $\begin{array}{c}\text { Cohesion Fund, } \\
\text { ERDF }\end{array}$ & ERDF & ESF & ERDF & ERDF & ERDF & ERDF \\
Million EUR & 966.67 & 220.90 & 559.87 & 649.04 & 2.5 & $1,132.78$ & 0.003 \\
$\%$ Share & 27.37 & 6.25 & 15.85 & 18.38 & 0.07 & 32.07 & 0.0001 \\
\hline
\end{tabular}

Source: based on the data of Zarząd Województwa Lubelskiego (2017), pp. 89-90.

During the period considered the Lubelskie voivodeship received, under the NCS and operational programmes, the co-financing from EU funds totalling EUR 3,531.786. The key source of support was the ERDF, from which the largest funds were received under the ROP in the Lubelskie voivodeship. Slightly less was obtained under the Infrastructure and Environment and Development of Eastern Poland Programme.

The total Cohesion Fund allocation for Poland (EUR 22.18 billion) was spent on the implementation of the largest in the history of EU Programme Infrastructure and Environment (IEP), with contributions from the ERDF (EUR 5.6 billion). An analysis of the division of IEP contracts by regions indicates that the following voivodeships: Mazovia, Silesian, Łódź, Pomeranian and Lower Silesian received over $50 \%$ of the EU subsidy. The Lubelskie voivodeship was ranked $11^{\text {th }}$ among all regions. Most EU funds in the Lubelskie voivodeship were received by road and air TEN-T networks (EUR 619 million) and environmentally friendly transport (EUR 105 million). In comparison to other voivodeships, the Lublin region recorded a higher value of co-financing under health safety and efficiency of the health care system ( $4^{\text {th }}$ place). The lowest positions were taken by the environmentally friendly transport and the energy security (13), and the water and sewage management (12). ${ }^{2}$

The total budget of the Human Capital Programme 2007-2013 (HCP) accounted for EUR 11.773 billion, including the entire ESF contribution in Poland (over EUR 10 billion). By the end of the HCP implementation, 4,300 co-financing agreements were concluded in the central component (I- $V$ and $X$ Priorities), for a total of EUR 3.44 billion, whereas in the regional component (VI-IX Priorities), 10 times more agreements were concluded (43.400) with the co-financing value amounting to EUR 8.8 billion. The largest value of subsidy in the regional system was given to the most populous voivodeships: Mazovian, Silesian, Małopolska and Wielkopolska. The next group, in terms of the amount of support, includes the Lubelskie voivodeship. The effects of the HCP implementation show the active participation of different types of beneficiaries from the Lublin region in the activities carried out within the priorities of the regional component. It was characterized one of the highest employment efficiency $(70.1 \%)$, thanks to the support (returnable and non-returnable) for starting the business activity. This ratio was even higher for young people in the age of $15-24$ and accounted for $73.8 \%$ of jobs, maintained after the implementation of the Programme (Ministerstwo Rozwoju, 2017, p. 259 and following). A high position was also taken by the employment effectiveness among beneficiaries, who included persons with a more difficult market situation due to their education, age,

${ }^{2}$ Final Report on the implementation of OP I\&E 2007-2013 Ministry of Infrastructure and Development, Warsaw 2017, pp. 7 and 58-198 as well as KS SIMIK 07-13. 
disability, long-term unemployment or rural origin. The Lublin region took the second place in terms of the ratio of enterprises included in the training support and a high number of people who completed the project.

The allocation of the ERDF for the Innovative Economy Programme 2007-2013 (IEP) accounted EUR 8.66 billion. The Lubelskie voivodeship was characterized by low activity of beneficiaries within the IEP (only 23 persons per 100,000 inhabitants received financing). Compared to other voivodeships, one of the lowest values of co-financing, in total and per capita (EUR 121.61) was also noted. The territorial distribution of support shows its concentration in the most developed regions and major cities, in particular the voivodeship cities. 240 contracts worth EUR 169.4 million were concluded in Lublin, representing $48 \%$ of the contracts and $43 \%$ of the total value of EU co-financing under the IEP for the entire region (Ministerstwo Rozwoju, 2017, pp. 9, 13, 61) The regional capital is the largest city and scientific centre in Eastern Poland. Hence, in comparison to other voivodeships of this macroregion, Lubelskie is distinguished by a higher share of support received for science and R\&D (over $3 \%$ of $11 \%$ of the total co-financing for Eastern Poland) and investments in research and development infrastructure. A relatively high value of funding was received for counselling and financial support for innovative SMEs, venture capital funds, business angel networks, etc. Among 128 individual projects, the Lublin region submitted only 4 projects.

An additional support of the ERDF (EUR 2.39 billion) for the five eastern voivodeships (Lubelskie, Podkarpackie, Podlaskie, Świętokrzyskie and Warmian-Mazurian) was the Development of Eastern Poland Programme (DEPP). The functions of the managing authority were performed by the Ministry of Regional Development. The Lubelskie region was the major beneficiary of the DEPP, both in terms of the quantity and value of contracts. However, this translated into the lowest average value of contracts on financing (EUR 7.84 million) among the analysed voivodeships. From the point of view of support areas, the most resources were allocated to transport $45 \%$, half less for the entrepreneurship and R\&D, 13\% of the co-financing for the social infrastructure, mainly for teaching facilities and $12 \%$ for the information society (Ministerstwo Rozwoju Regionalnego, 2017, p. 22). Under the Programme were implemented a total of 17 large projects, of which 4 were in the Lubelskie voivodeship.

More than EUR 17 billion was allocated to the Regional Operational Programmes, which accounted for $1 / 4$ of the allocation from the ERDF. 3,129 projects co-financed by the EU, of a total value of EUR 1,135.6 million, were implemented under the ROP in the Lublin region. The analysis of the intra-regional distribution of support shows that every third project co-financed under the Programme came from Lublin, then from the Lublin county, the Puławy county and the Biała Podlaska county. The first three of the counties also received the most funds from the ERDF. The least projects were submitted from the following counties: Hrubieszów, Janów Lubelski and Radzyń. The least funds were received by the city of Chełm and the Opole Lubelskie county (Zarząd Województwa Lubelskiego, 2017, pp. 88-90). Significantly more projects were implemented in cities (2160), with Lublin on the top, than in rural areas (969). The companies dominate in terms of the number of projects (especially micro and small enterprises, then medium). However, the highest value of funding was received by self-government, especially communes and their organizational units. The dominant area of support is the transport (1/4 allocation). Subsequent position were taken by: R\&D, innovations, entrepreneurship (23\%), social infrastructure (almost 13\%), environmental protection and risk prevention $(9 \%)$, energy sector $(7.8 \%)$, culture $(5.6 \%)$, information society $(5.3 \%)$, urban and rural renewal $(4.4 \%)$ and tourism (4.3\%).

Between 2007 and 2013 Poland participated in 10 European Territorial Cooperation programmes and in 2 cross-border programmes under the European Neighbourhood and Partnership Instrument. The Lubelskie voivodeship was a beneficiary of only the latter cross-border program: The Poland - Belarus - Ukraine. The program 
budget amounted to EUR 202.9 million (including EUR 186.2 million from the ERDF). Beneficiaries from the three subregions of the Lublin voivodeship (including the Biała Podlaska subregion and the Chełm-Zamość subregion as the main support areas and the Lublin region as an adjacent area) received almost $1 / 4$ of support from the Program. It included a total of 8 subregions from 4 voivodeships in this part of Poland, 15 support areas in Belarus and 6 in Ukraine. The highest subsidies were received by the projects concerning the competitiveness of the border area (Priority 1). Priority 2 focused on improving the quality of life, whereas Priority 3 - on networking and local community initiatives. Most of the operational programmes implementing the EU cohesion policy was continued in the next financial perspective.

\section{Participation of the Lublin region in EU conesion policy funds in the years 2014-2020}

In the new programming period, the European funds system implements the Europe 2020 strategy and its eleven thematic objectives. The new Regulations Package includes a general regulation establishing common rules and principles for the five European Structural and Investment Funds (ESIF) and specific regulations for each of them (ERDF, ESF, Cohesion Fund, EAFRD and EMFF). The CSF details the system of implementing the ESIF in Member States and regions in the Partnership Agreement and programmes. The cohesion policy focuses on two priority objectives: Investments in economic growth and employment, and the European territorial cooperation. The first objective is supported by all funds. The level of co-financing depends on the category of the region (based on GDP per capita). For the first time in Poland there are two categories of regions: more developed Mazovian voivodeship (with PKB per capita above $90 \%$ of the EU average) and the remaining less developed 15 voivodeships (with PKB per capita below $75 \%$ of the EU average).

The total support for Poland amounts to EUR 82179.22 million has been allocated to 8 national and 16 regional programmes, the ETC programmes and initiatives co-financed by individual ESFI funds. The OP IE co-financed with the Cohesion Fund (EUR 22.5 billion) and the ERDF (EUR 4.9 billion) remains the largest national programme. It implements 10 Priority Axes, including six nationwide Axes and Axes IV, VII, VIII and IX, under which the less developed regions can receive EUR 5524.08 million (Ministerstwo Infrastruktury i Rozwoju 2014, pp. 106-109). The Lubelskie voivodeship plans to increase its participation in the programme, by submitting 9 large projects (including key projects for the construction of expressways within the road S17, S19, S12 and the bypass, the railway line No. 7 and the construction of the $400 \mathrm{kV}$ power line from Chełm to Lublin). The IEP support was dominated by the transport ( $72 \%$ of allocation), followed by environment $(2.8 \%)$, energy sector $(10 \%)$, health and culture (each approx. 1.7\%).

Another important national programme, from the point of view of the Lublin region, is the Eastern Poland (OP EP), which is a continuation of the DEPP and is directed to the same five voivodeships. However, the allocation of the ERDF under the current Programme has been reduced by $16 \%$ and distributed among 4 Priority Axes: Entrepreneurial Eastern Poland (35.97\%), Modern Transport Infrastructure (45.81\%), Supra-regional Railway Infrastructure (16.52\%) and Technical Assistance (1.7\%) (Ministerstwo Rozwoju 2017, p. 18). As a result, the OP EP focuses on supporting accessibility, the transport by road and rail, as well as increasing the use of public transport in Lublin and its functional area (over $62 \%$ of the ERDF funds), whereas almost half less is allocated for the support of innovative companies, especially SMEs and start-ups.

Two programmes were launched in place of the IEP: Smart Growth (OP SG) and Digital Poland (OP DP). Under the OP SG 15 voivodeships can receive support from the ERDF in the amount of 7,854.56 million for projects 
corresponding to five priorities. The largest resources were provided for R\&D in enterprises (44\% of allocations), enterprise innovativeness $(25.5 \%)$, as well as an increase of research potential $(14.5 \%)$ and the environment and potential of enterprises to operate B+R+I (12\%) (Ministerstwo Infrastruktury i Rozwoju, 2014, p. 138-139). Out of the total ERDF allocation for the OP DP for the less developed regions, EUR 2023.44 million were reserved mainly for the promotion of Internet access (45\%) as well as the e-government and open government (43.6\%), and raising the digital literacy of inhabitants (6.7\%) and TA (Ministerstwo Infrastruktury i Rozwoju, 2014, p. 48). The Knowledge Education Development (OP KED) 2014-2020 is a national programme and does not have a regional component. Its budget covers $34 \%$ of the ESF allocation for Poland (the remainder goes to the ROP), 252.4 million from the Youth Employment Initiative (YEI) special budget line and national contribution. However, the distribution of ESF funds between the two categories of regions accounts i.e. $86.14 \%$ for the less developed voivodeships. The OP KED resources were concentrated on six priority axis, in particular the support of young people on the labour market ( $30 \%$ of the ESF contribution in less developed regions and the allocation of the YEI), higher education ( $25 \%$ of the ESF), public labour market efficiency (17.6\%), social innovation and transnational cooperation (16\%), health support (7\%)e. YEl qualified for 10 voivodeships, where youth unemployment (15-24-years-olds) exceeded $25 \%$. The Lublin region will not be supported by YEI.

Compared to the previous programming period, more than $80 \%$ of structural funds will be received by the regional operational programmes. Most of this allocation (EUR 29.2 billion) was divided among 15 less developed regions. According to the adopted algorithm for the division of funds the Lubelskie voivodeship will take sixth place and receive $7.6 \%$, i.e. EUR 2230.96 million. The ROP Lubelskie budget was divided into 14 Priority Axes (including technical assistance). The highest EU support was provided for enterprises, in particular micro, small and mediumsized enterprises (approx. 20\%), improvement of the energy efficiency and RES (18\%), regional and local road and rail transport (12.7\%), social infrastructure and labour market activation (over 10\% each). There is a generally positive view of effectiveness of objectives relating to different forms of infrastructure in the Lubelskie voivodeship.

Table 2. Selected indicators of technical infrastructure, enterprises and labour market in the Lubelskie voivodeship

\begin{tabular}{lccccc}
\hline Dimensions (measure unit) & 2004 & 2007 & 2010 & 2013 & 2016 \\
\cline { 2 - 6 } Public roads with hard surface per $100 \mathrm{~km}^{2}(\mathrm{~km})$ & 71.4 & 73.7 & 80.5 & 84.5 & 87.4 \\
Expressways and motorways per 100 km $(\mathrm{km})$ & - & 0.02 & 0.02 & 0.19 & 0.35 \\
Standard-gauge electrified railways $(\mathrm{km})$ & 378 & 405 & 409 & 413 & 416 \\
\% share of passenger traffic in airports, Poland =100 & 0.0 & 0.0 & 0.0 & 0.8 & 1.1 \\
Persons using water supply in \% of total population & 78.4 & 79.8 & 81.1 & 81.9 & 86.9 \\
Persons using sewage system in \% of total population & 44.3 & 45.9 & 47.2 & 49.7 & 52.5 \\
Persons using gas supply system in \% of total population & 36.4 & 38.1 & 39.2 & 40.1 & 40.7 \\
Households furnished with computer with Internet access \% & 14.6 & 28.1 & 50.6 & 65.4 & 69.5 \\
Entities entered in the REGON register per 10 thous. popul. & 684 & 699 & 753 & 787 & 816 \\
Enterprises expenditures on innovation activity (thous. PLN) & - & $552.83^{*}$ & 592.84 & 532.57 & 630.15 \\
Economic activity of the population in aged 18-59/64 & 71.2 & 72.2 & 72.2 & 74.0 & 74.2 \\
Rate of registered unemployment, Poland =100 (\%) & 93.7 & 116.1 & 105.6 & 107.5 & 125.6 \\
\hline
\end{tabular}

*B By the year 2006.

Source: Local Data Bank.

Based on objectives of the Programmes, they were met and infrastructures project were delivered, contributing to overcoming of the infrastructure gap and improvement the quality of life. Infrastructure and transport is a prerequisite though insufficient for competitiveness enhancement (Jóźwik, 2013, p. 44). From the point of view 
of endogenous growth, innovation is essential, and their source is private entrepreneurship and human capital (Murzyn, 2010, pp. 226-227; Olechnicka, 2007, pp. 55-74). As a poorly urbanized area, there are no large growth centres beside the capital (Biała Podlaska, Chełm, Puławy and Zamość act as subregional centres). The thematic and territorial nature of the EFSI intervention has been highlighted for the years 2014-2020, as evidenced by the integrated territorial investment (ITI), community driven local development (based on LEADER experience) and joint action plans. ITIs are implemented under the ROP and indirectly under the national programmes (IEP and the Eastern Poland) as an instrument of support for cities and their functional areas. Lublin and its Functional Area (LFA) is one of the 17 ITI areas for voivodeship cities and will receive EUR 105.4 million, i.e. 5\% of the ROP allocation. Moreover, four subregional cities (Biała Podlaska, Chełm, Puławy and Zamość) will implement the Strategic Territorial Investments, on which $2.9 \%$ of the ROP allocation will be spent. The support for rural areas represents in total approx. $50 \%$ of the Programme allocation (i.e. The Community-led Local Development). Interventions financed under the ROP are complementary to the ETC programmes. One of the eight Polish projects submitted to the Transnational Cooperation Programme Central Europe with a value of EUR 16.132 million from the ERDF, comes from the Lubelskie voivodship. Six projects from the Lublin region, were qualified in the selection procedures for the interregional cooperation programme Interreg Europe. In addition, the areas of the PolandBelarus-Ukraine Programme continue the cooperation supported by the European Neighbourhood Instrument and the ERDF (PLN 183 million in total).

\section{Conclusions}

In the period of Polish membership in the EU the external convergence is faster than the internal. The regional income per inhabitant of Eastern Poland remains low compared to the EU average (from $47 \%$ in the Lubelskie). However, in the years 2010-2015 the GDP growth in the Lublin region is noticeably faster in comparison to the regions of Eastern Poland (with the exception of the Podkarpackie), as well as the Kuyavian-Pomerania and Opolskie voivodeships. The largest funds from the EU were received by the richest and better developed voivodeships. Thanks to the establishment of a separate programme for this macro-region and the use of ROP allocation, the participation of Lublin region in the acquisition of EU subsidies is growing. The "catching up" process takes place in the Lublin region at the lower level of development and requires many years of structural changes (Kudełko, 2013, p. 214). The Lublin region is still characterized by low industrialization and a high share of agriculture in the GVA (almost twice as high as the national average), and on the other hand, there is an above-average share of the services sector $(66.2 \%$ vs. $62.8 \%$ for the country). Both in terms of the quantity and value of concluded contracts on the EU subsidies, Lublin was the leader (EUR 860.6 per inhabitant of the capital vs. EUR 530.66 in the voivodeship under the ROP co-financing 2007-2013). The largest EU support for the Lubelskie voivodeship in the years $2007-2013$ was spent on transport (24.87\% under the ROP and $42.46 \%$ within the national programmes supported by the EFRR), enterprises, research and innovation (22.8\% - ROP and $15.67 \%$ - national programmes), and subsequent position are taken by the social infrastructure (including higher education). During the current programming period it is planned to increase funding for enterprises, strengthening the cooperation between science and business, low carbon economy and RES, labour market and social inclusion. The participation in the Cohesion Fund will be increased thanks to the co-financing of major road, rail and energy projects under the OP IE 2014-2020. The requirements for large investments, including the provision of own contribution, constitute 
an obstacle for the use of this programme. The greater emphasis of the EU on the use of extra-support mechanisms encourages a greater use of repayable funding.

\section{References}

Bachtler, J., Berkowitz, P., Hardy, S., Murvska, T. (eds.) (2016). European Cohesion Policy. Reassesing performance and direction. London: Routledge.

Bradley, J., Untiedt, G., Zaleski, J. (2009). The Economic Return of Cohesion Expenditure for Member States. Brussels: the European Parliament's Committee on Regional Development.

Churski, P., Perdał, R., Herodowicz, T. (2016). Rola środków polityki spójności pozyskiwanych przez samorząd terytorialny w rozwoju społeczno-gospodarczym ośrodków regionalnych w Polsce. Samorząd Terytorialny, 7-8, 96-115.

European Commission (2014). Szósty raport na temat spójności gospodarczej, społecznej i terytorialnej. Retrieved from: http:// ec.europa.eu/regional_policy/sources/docoffic/official/reports/cohesion6/6cr_pl.pdf.

European Commission (2014). Partnership Agreement for Poland 2014-2020. Brussels.

Eurostat \& Gross Domestic Product Regional Account in 2010 (2012). Katowice: Central Statistical Office, Statistical Office in Katowice.

Gorzelak, G. (ed.) (2007). Polska regionalna i lokalna w świetle badań EUROREG-u. Warszawa: Wydawnictwo Naukowe Scholar.

Gorzelak, G., Goh, Ch., Fazekas, K. (eds.) (2012). Adaptability and change: the regional dimensions in Central and Eastern Europe. Warszawa: Wydawnictwo Naukowe Scholar.

Halmai, P., Vásáry, V. (2010). Real Convergence in the New Member States of the European Union (Shorter and Longer Term Prospects). European Journal of Comparative Economics, 7 (1), 229-253.

Jankowska, A., Kierzkowski, T., Knopik, T. (2005). Fundusze Strukturalne Unii Europejskiej. Warszawa: C.H. Beck.

Jóźwik, B., Sagan, M. (eds.) (2013). Eastern Poland. Development challenges. Lublin: Instytut Europy Środkowo-Wschodniej.

Kaczor, T., Mackiewicz-Łyziak, J., Michniewicz, M. (2011). Wpływ realizacji polityki spójności na kształtowanie się głównych wskaźników dokumentów strategicznych NPR 2004-2006 i NSS 2007-2013. Warszawa: IBnGR.

Kudełko, J. (2013). Uwarunkowania i kierunki rozwoju województw Polski Wschodniej jako regionów słabo rozwiniętych. Warszawa: Studia KPZK PAN T.CLI.

McCann, P. (2015). The Regional and urban policy of the European Union. Cohesion, results-orientation and smart specialisation. Cheltenham, Northhampton: Edward Elgar Publishing.

Ministerstwo Infrastruktury i Rozwoju (2017). Sprawozdanie końcowe z realizacji programu operacyjnego Infrastruktura i Środowisko 2007-2013. Warszawa.

Ministerstwo Infrastruktury i Rozwoju. (2014). Program Operacyjny Inteligentny Rozwój 2014-2020. Retrieved from: https://www.poir. gov.pl/media/1867/ost_POIR_19_01_dokument_21012015_okladka.pdf.

Ministerstwo Infrastruktury i Rozwoju. (2014). Program Operacyjny Infrastruktura i Środowisko 2014-2020, (po aktualizacji dużych projektów w marcu 2017). Warszawa.

Ministerstwo Rozwoju Regionalnego (2008). Doświadczenia i szanse regionów. Przegląd Regionalny, 2.

Ministerstwo Rozwoju Regionalnego (2010). Końcowy raport z postępu wdrażania ZPORR 2004-2006.

Ministerstwo Rozwoju Regionalnego (2017). Program Operacyjny Polska Wschodnia 2014-2020. Warszawa.

Ministerstwo Rozwoju Regionalnego (2017). Sprawozdanie końcowe z realizacji programu operacyjnego Innowacyjna Gospodarka 2007-2013. Warszawa.

Ministerstwo Rozwoju Regionalnego (2017). Sprawozdanie końcowe z realizacji programu operacyjnego Rozwój Polski Wschodniej 2007-2013. Warszawa.

Ministerstwo Rozwoju Regionalnego (2017). Sprawozdanie końcowe z wdrażania programu operacyjnego Kapitał Ludzki $2007-2013$. Warszawa.

Murzyn, D. (2010). Polityka spójności Unii Europejskiej a proces zmniejszania dysproporcji w rozwoju gospodarczym Polski. Warszawa: C.H. Beck.

Olechnicka, A. (2007). Innowacyjność polskich regionów. In: G. Gorzelak (ed.), Polska regionalna i lokalna w świetle badań EUROREG-u. Warszawa: Wydawnictwo Naukowe Scholar. 
Rapacki, R., Próchniak, M. (2010). Wpływ rozszerzenia Unii Europejskiej na wzrost gospodarczy i realną konwergencję krajów Europy Środkowo-Wschodniej. Ekonomista, 4, 523-546.

Rodrigues-Pose, A., Fratesi, U. (2004). Między rozwojem a polityką społeczną: oddziaływanie europejskich funduszy strukturalnych w regionach celu 1. Studia Regionalne i Lokalne, 3 (17), 5-32.

Smętowski, M., Wójcik, P. (2009). Regiony w Europie Środkowo-Wschodniej: tendencje i czynniki rozwojowe. Warszawa: Raporty i Analizy EUROREG nr 3.

Swianiewicz, P. (2012). Środki unijne w samorządach - kto korzysta najwięcej. Samorząd Terytorialny, 5, 9-24.

Szafran, J. (2010). Implementacja unijnej polityki regionalnej w Polsce. Lublin: Wydawnictwo UMCS.

Tomaszewski, P., Zaleski, J., Zembaty, M. (2011). Oczekiwane efekty realizacji polityki spójności Unii Europejskiej na poziomie regionalnym w Polsce. Studia Regionalne i Lokalne, 2 (44), 92-117.

Zarząd Województwa Lubelskiego (2017). Sprawozdanie końcowe z realizacji RPO WL na lata 2007-2013. Lublin.

Cite this article as: Szafran, J. (2018). The Lubelskie region as a beneficiary of the EU cohesion policy funds - experiences and prospects. European Journal of Service Management, 3 (27/2), 433-443. DOI: 10.18276/ejsm.2018.27/2-53. 